\title{
Germination and initial growth of tree seedlings on deforested and natural forest soil at Dulhazara, Bangladesh
}

\author{
Md. Mohitul Hossain \\ Institute of Forestry and Environmental Sciences, University of Chittagong, Chittagong-4331, Bangladesh; \\ mohitulh@yahoo.com
}

Received 11-II-2011. Corrected 20-IV-2012. Accepted 29-V-2012.

\begin{abstract}
The destruction of natural forest is increasing due to urbanization, industrialization, settlement and for the agricultural expansion over last few decades, and studies for their recovery need to be undertaken. With this aim, this comparative study was designed to see the effects of deforested soil on germination and growth performance of five different tree species. In the experiment, five species namely Gmelina arborea, Swietenia mahagoni, Dipterocarpus turbinatus, Acacia auriculiformis and Syzygium grande were germinated for six weeks on seedbeds and raised in pots $(25 \mathrm{~cm}$ diameter, $30 \mathrm{~cm}$ height $)$, that were filled with two soil and type of land use: deforested and adjacent natural forest of Dulhazara Safari Park. Growth performance of seedling was observed up to 15 months based on height, collar diameter and biomass production at the end. Our results showed that the germination rate was almost similar in both type of land uses. Height growth of D. turbinatus, G. arborea and S. mahagoni seedlings was almost similar and A. auriculiformis and $S$. grande lower in deforested soil compared to natural forest soil, while collar diameter of A. auriculiformis, G. arborea, S. grande and $S$. mahagoni lower and D. turbinatus similar in deforested soil compared to natural forest soil. After uprooting at 19 months, $S$. mahagoni seedlings were showed significantly $(\mathrm{p} \leq 0.05)$ higher oven dry biomass, D. turbinatus and A. auriculiformis higher, while G. arborea showed significantly $(\mathrm{p} \leq 0.05)$ lower and $S$. grande almost similar oven dry biomass in deforested soil compared to natural forest soil. Oven dry biomass of D. turbinatus seedlings at 19 month age in deforested soil was $21.96 \mathrm{~g}(\mathrm{n}=5)$ and in natural forest soil $18.86 \mathrm{~g}(\mathrm{n}=5)$. However, differences in germination rate and growth performance for different tree species indicated that soil are not too much deteriorated through deforestation at Dulhazara and without any failure such deforested lands would be possible to bring under forest through plantation. Rev. Biol. Trop. 60 (4): 1479-1489. Epub 2012 December 01.
\end{abstract}

Key words: deforestation, growth performance, dry biomass, desiccators, Dulhazara Safari Park, Bangladesh.

Deforestation has become a severe phenomenon in all over the world, particularly in developing countries in the recent years. It has been an issue of the global environmental agenda for many years, but remains a serious problem till today. In the tropics and many other parts of the world, nations continue to lose their natural forests along with its valuable biodiversity. Nearly one half of the forests, that once covered the earth, have been converted into farms, pastures and other land uses (FAO 1995). Large areas of deforested and degraded land particularly exist in the humid tropics. Tropical forests of the world that existed around 1960, about 25\% have been cleared during 1970s. Tropical countries were deforested at an annual rate of 11 million ha in 1970s, this rate increased to about 16.3 million ha in 1980s and somewhat fallen to 14.6 million ha in 1990s (FAO 2001). After accounting new plantations, the net annual deforestation amounted to 13.1 million ha in 1980 s and 9.4 million ha in 1990s. If this rate continues, all tropical forests may be destructed by the year 2050 (Dinerstein et al. 1995). Bangladesh is not an exception, which also experienced with a considerable deforestation rate (Evans 1982). Bangladesh once endowed with dense forest, 
has suffered forest decrease at an alarming rate due to rapid population growth and human poverty, expansion of agricultural land for producing more food for the increased population, shortage of fuel wood, fodder and timber, land encroachment, habitation, urbanization and industrialization. Total forest land in Bangladesh is about 2.53 million ha corresponding to $17.50 \%$ of the surface area of the country; this represents the lowest ( $0.02 \mathrm{ha}$ ) per capita forest resources in the world (FMP 1992). The annual deforestation rate in Bangladesh is about 3.3\% in comparison to $0.6 \%$ in South Asia (Rasul $\&$ Kakri 2007). The amount of forest cover in Bangladesh was reduced from $15.6 \%$ in 1973 to $14.6 \%$ in 1985 and eventually to $13.4 \%$ in 1987, while minimum of $25 \%$ forest cover is suggested for a healthy ecosystem. Amount of forest cover in Bangladesh at the present time believed to be less than 10\% (FRA 2000). Among the three major forest categories: hilly, inland and mangrove, the hill forests constituting $48 \%$, are the most important watershed of the country and composed of tropical evergreen and semi-evergreen tree species (Douglas 1981). The hill forest supplies around 40\% of the commercial timber of the country. This over exploitation of forest resources makes vulnerable the major species of the forest such as Dipterocarpus turbinatus (Garjan), Gmelina arborea (Gamar), Artocarpus chaplasha (Chapalish), Toona ciliata (Toon), Albizia spp. (Koroi), Bombyx ceiba (Simul), Swintonia floribunda (Civit), Tetrameles nudiflora (Chandul) and Michelia champaca (Champa). The obvious effect of deforestation in most places are the complete loss of trees with undergrowth vegetation and in some places only presence of bushy vegetation. A rapid deforestation of hill forests not only diminishes vegetative cover and species diversity, it also accelerates surface runoff, increase soil erosion and deteriorate soil biochemical properties, and often affects climate by releasing stored soil carbon as $\mathrm{CO}_{2}$ into atmosphere (Houghton 1990, Islam \& Weil 2000). Deforestation also deteriorates soil quality through loss of organic matter and nutrient elements with the removal of forest vegetation and top fertile soil (Pritchett \& Fisher 1987, Islam \& Weil 2000).

In Bangladesh, there is limited or no scope for horizontal expansion of forest. So, the vast tracts of deforested and degraded lands could be reforested with suitable species to alleviate widespread deforestation (Islam et al. 1999). Many of such areas are difficult to do afforestation due to loss of potentiality to support tree growth. For the better utilization of deforested and degraded lands, a good management plan is required, and in this regard, information of site potentiality to support initial seedlings growth of different species on similar site is essential. As nutrient requirement of different species are different and also differ with environmental conditions. If a particular nutrient is deficient, seedlings may compensate to some extent by increasing capacity to take up the deficient ion. But, deficient of several necessary nutrients alongside environmental deterioration may cause failure of plantation. Both in national and international level, many studies (Ahmed 1990, Mahmud et al. 2005, Lusiana et al. 2004, Carpenter et al. 2004, Roshetko \& Purnomosidhi 1999) were conducted on survival rate and growth performance of different tree species. However, all the studies were conducted using different media and fertilizers, but no research has been conducted to magnify the effect of deforested soil on the germination and initial growth of tree seedlings. This experiment was therefore, undertaken (i) to see the potentiality of deforested land of Dulhazara on seed germination and seedlings growth, and (ii) to find potential species to rehabilitate such degraded lands.

\section{MATERIALS AND METHODS}

General description of the area: Dulhazara is an important natural Dipterocarpus turbinatus forest belt in Chittagong-Cox's Bazar region. Dulhazara Safari Park is under the administration of Wildlife Management and Nature Conservation Division, Chittagong, Bangladesh. The study area of the park lies between $20^{\circ} 43^{\prime}-21^{\circ} 56^{\prime} \mathrm{N}$ latitudes and 
between $91^{\circ} 50^{\prime}-92^{\circ} 23^{\prime}$ E longitudes beside Chittagong-Cox's Bazar road. Topography of the park is almost flat to little undulating with a slope of zero to $4 \%$. Approximately $10 \%$ of the landscape is occupied by flood plains in Cox's Bazar region (Chowdhury et al. 2004). Soils on the alluvial plains and valleys are mainly of silty loam to silty clay loam soil and neutral to medium acidic in reaction (WCMC 1998). Locally soils are sandy loam on ridges and clayey to silty clay in depressions. Raised areas in the region are well drained and narrow valleys retain moisture all the year (Mabud 2001). Climate in the region is moist tropical maritime with mean annual temperature $25^{\circ} \mathrm{C}$ and mean annual rainfall $261.60 \mathrm{~cm}$, most of which fall between June to October. The region experiences high humidity, except in the hot dry season, and winter heavy dew and thick mist. From this region, a natural forest site and a deforested site were selected to take the soil samples for the study:

Natural forest of Dulhazara Safari Park: Natural forest Dulhazara Safari Park is characterized by the presence of dominant species such as Dipterocarpus spp., Syzygium spp., Albizia spp. and shrub species like Clerodendrum indicum, Mussaenda roseburghii, Melastoma malabatricwn among others, with several natural and artificial lakes. Tree canopy coverage of the forest was ranged from $10-50 \%$, and undergrowth coverage varied from $40-100 \%$. There was no grass vegetation, but existence of remarkable amount of litter on the forest floor. Tree size varied greatly in this natural forest. Mean height of the dominant species was $30 \mathrm{~m}$ with close canopy coverage. Four types of bamboos and two types of canes occurred in this park.

Deforested land of Dulhazara: About five years before, the deforested land possessed similar ecological characteristics as exists today in the natural forest vegetation of Dulhazara Safari Park. Nowadays, the site includes small sized scattered distribution of Hollarrhena antidycenterica, Dipterocarpus turbinatus,
Emblica officinalis, Cimmamomum spp., Ficus benghalensis, Syzygium fruticosum and others, with herbs and shrubs of 1-2.5m height giving coverage of $30-40 \%$. No litter coverage was found on the floor due to complete burning.

Soil profile study: One soil profile was dug in each type of land, i.e. natural forest land and deforested land, to see the variation in soil layer. Soil profile was dug at right angles to the slope to avoid any consistent spatial variation in soil physical properties. Each profile in the field was divided into horizons based on variations in a number of properties including color, degree of mottling, structure, compactness, consistency, internal drainage and root characteristics. In the experiment upper litter layer comprised of fresh, partially decomposed and completely decomposed litter and designated as O-horizon. Soil color was determined using a Munsell color chart (1954).

Germination experiment: To determine the germination capabilities of seeds of selected tree species on deforested and forest soils, six seedbeds were set up within the park. Three seedbeds were set up within the Safari Park using sieved (No.12) natural forest soil and another three by using sieved soil from the adjacent deforested land (Fig. 1). Apparently same quality seeds of five different tree species namely Gmelina arborea, Swietenia mahagoni, D. turbinatus, Acacia auriculiformis and Syzygium grande were collected from local nursery. Drills were made up to $6 \mathrm{~mm}$ depth in the sand at $2.5 \mathrm{~cm}$ intervals in each seedbed. Ten seeds of each species irrespective of seed size were sown in each of the six seedbeds i.e. 30 seeds of each species in forest soil seedbeds and another 30 seeds in deforested soil seedbeds. The soil was lightly watered again with a fine mist spray and germination of seeds was followed for six weeks.

Growth performance experiment: To see the effect of deforested soil on growth performance, five species namely $G$. arborea, $S$. mahagoni, D. turbinatus, A. auriculiformis and 

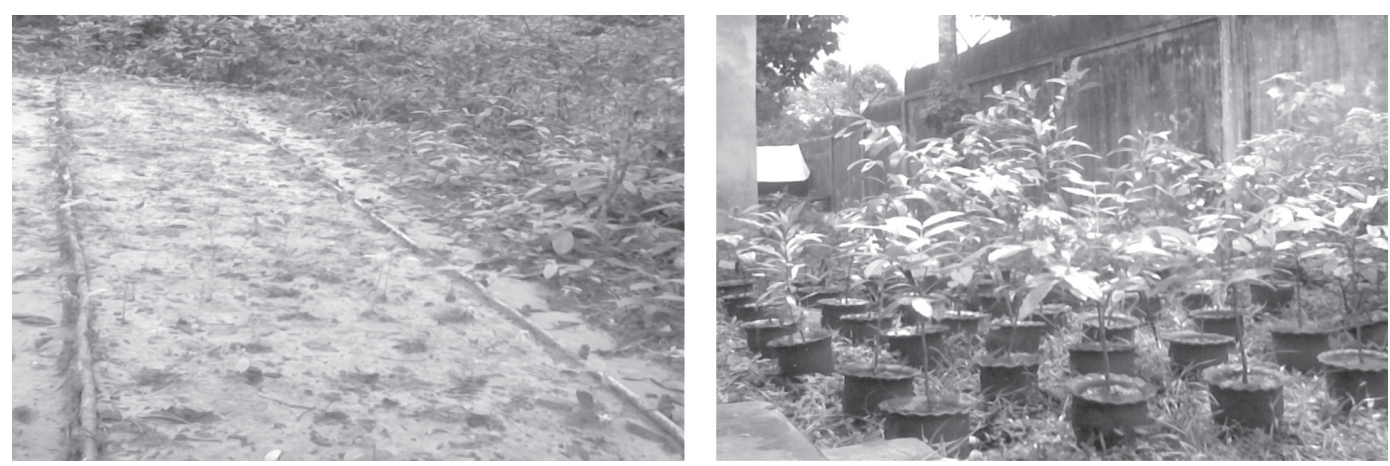

Fig. 1. Germination test (left side) and growth performance assessment by pot culture (right side) on natural forest soil and deforested soil at Dulahazara, Bangladesh.

S. grande were raised in earthen pots in Dulhazara Safari Park. These species were chosen for the experiment because they are normally found in plantation forests in this region. For the experiment, soils were collected at a depth of $0-25 \mathrm{~cm}$ from both natural forest and deforested land of Dulhazara Safari Park in 31 October, 2007. From each land use, five soil samples were collected randomly and mixed together to fill the pots. The earthen pots of diameter $25 \mathrm{~cm}$ and height $30 \mathrm{~cm}$ were used for the experiment. For each species five pots were filled with soils from natural forest and other five with deforested soil. Same sized seedlings of one and half month aged were uprooted from the experimental seedbeds of germination and directly planted on each of the pots in October 31, 2007. Pots with forest soils were kept within the Safari Park and pots with deforested soils were set up in the adjacent deforested land. Watering was done in a controlled way to avoid the leaching out of nutrients from the soil.

Height and collar diameter of seedlings were measured, after transplanting of seedlings from seed bed to the pots, using scale and slide caliper at $5 \mathrm{~cm}$ above from pot soil, respectively; measurements were taken at three months interval and continued up to 15 month after planting. A. auriculiformis and S. mahagoni seedlings were uprooted on April 15, 2009 and $D$. turbinatus, S. grande and G. arborea seedlings were uprooted on May 10, 2009. Then, green and dry weight of the seedlings was determined in the following way:

Green weight of seedling: All the seedlings uprooted using shovel in such way that roots of seedling remain undisturbed. Before uprooting each pot, sufficient water was added to make the soil loose. After uprooting, all the three parts: leaf, branch and root of seedlings were separated using bypass secateurs. Then weight of each part was taken using an electronic balance (EK-120i, 0.01g precision). The green weight of all three parts was added to give whole weight of each seedling.

Oven dry weight of seedlings: Moisture content of each seedling was determined from three different plant parts namely root, branch and leaf separately. For each plant part, three replicated samples were taken and dried in the oven at $70^{\circ} \mathrm{C}$ for four days. Then samples were taken out and kept in desiccator for cooling and weighted in balance. Moisture content of samples was calculated as follows:

$$
\text { Moisture }(\%) \text { of each plant part }=\frac{\text { Green weight }- \text { Oven dry weight }}{\text { Oven dry weight }} \times 100
$$

Dry weight of each part $=$ Green weight of each part - Moisture content of each part

Total dry weight of the whole seedling $=$ Dry weight of $($ root + branch + leaf $)$ 
One way analysis of variance (ANOVA) was done for each growth data obtained from deforested and natural forest soil seedlings to determine any growth difference between the two analyzed land uses using statistical package SPSS 16.

\section{RESULTS}

Soil profiles: Soil profile characteristics of deforested and natural forest soils differed in relation to characteristics of soil colour, structure, consistency, internal drainage and root characteristics. Slight variation was observed in the upper horizons of deforested land soil profile compared to the natural forest soil. Their characteristics are presented below:

\section{Soil profile of deforested land}

A1: 0-17cm; 7.5YR 4/2, brown (dry); sandy clay loam weak medium sub angular blocky; slightly sticky, slightly plastic, friable, slightly hard; common medium tabular pores; few medium and fine roots; crotovina; $\mathrm{pH} 3.02$; clear smooth boundary.

B1: $17-50 \mathrm{~cm}$; 10YR 5/6, yellowish brown (moist) with $7.5 \mathrm{YR} 4 / 3$, brown patches along ped faces; sandy clay loam; strong large sub angular blocky; soft iron-clay nodules; sticky, plastic, friable, hard; few medium tabular pores; few medium roots; crotovina; hard and compact soil; $\mathrm{pH} 3.31$; diffuse smooth boundary.

B2: $50-110+\mathrm{cm} ; 7.5 Y R$ 5/6, strong brownish (moist); clay loam; strong large sub angular blocky; Common fine and medium tabular pores; few very fine and fine roots; crotovina; sticky, plastic, friable, hard; $\mathrm{pH}$ 3.20; few soft reddish brown (5YR 4/4) iron concretions.

\section{Soil profile of natural forest}

O: $0-4.5 \mathrm{~cm}$; litter layer.

A1: $4.5-20 \mathrm{~cm} ; 7.5 \mathrm{YR} 5 / 6$, strong brown(dry) with few 7.5 YR 4/1, dark grey nodules and few 7.5 YR 5/8, strong brown mottles; sandy clay loam; weak medium subangular blocky; slightly sticky, plastic, very friable, slightly hard; few fine and medium tabular pores; common fine and medium roots; $\mathrm{pH}$ 3.60; diffuse smooth boundary.

B1: 20-50cm; 10YR 5/6, strong brown (moist) with common fine 5YR 4/6, yellowish red mottles; sandy clay loam; moderate medium angular blocky; light brownish grey (10YR 6/2) staining along ped faces; many black Mn concretions; sticky, plastic, friable, hard; few fine and medium tabular pores; few fine to very coarse roots; $\mathrm{pH} 3.46$; diffuse smooth boundary.

B2: $50-90+\mathrm{cm} ; 2.5 \mathrm{YR} 4 / 6$, red and $5 \mathrm{YR} 5 / 4$, yellowish brown (moist) with $2.5 \mathrm{YR} 4 / 6$, red staining along pores and ped faces; sandy clay loam; moderate medium angular blocky; few black Mn concretions; common fine and medium tabular pores; few very fine and medium roots; non sticky, plastic, friable, hard; $\mathrm{pH} 4.20$.

Germination performance: There was no substantial difference found in germination for the studied species in both type of soils, except for $G$. arborea, that was much higher in natural forest $(26.66 \%)$ than in deforested land (16.66\%). Among the other species, $A$. auriculiformis and S. mahagoni showed a little lower germination while $S$. grande and $D$. turbinatus showed a little higher germination in deforested soil compared to natural forest soil. Overall, A. auriculiformis showed the highest germination rate, followed by $S$. grande and S. mahagoni, and the lowest was found for $G$. arborea. Besides, fairly large amount of seeds were damaged in both type of seedbeds. The highest damaged seeds were found for $G$. arborea i.e. $53 \%$ in forest soil seedbeds and $70 \%$ in deforested soil seedbeds. The second species with higher damaged seeds was $S$. grande. Near about $50 \%$ seeds of these two species were destroyed in the deforested land experiment (Table 1). Excluding damaged seeds, lower germination power was found for D. turbinatus, i.e. higher amount of seeds were not germinated in both type of land uses. 
TABLE 1

Germination percentage of the studied species in seedbeds of natural forest and deforested land soils at Dulahazara, Bangladesh

\begin{tabular}{|c|c|c|c|c|c|}
\hline \multirow{2}{*}{ Species } & \multirow{2}{*}{$\begin{array}{l}\text { Germination } \\
\text { status }\end{array}$} & \multicolumn{2}{|c|}{ Natural forest soil } & \multicolumn{2}{|c|}{ Deforested land soil } \\
\hline & & $\left(\mathrm{N}^{\circ}{ }^{\circ}\right)$ & $(\%)$ & $\left(\mathrm{N} .{ }^{\circ}\right)$ & $(\%)$ \\
\hline \multirow[t]{3}{*}{ Gmelina arborea } & Germinated & 8 & 26.66 & 5 & 16.66 \\
\hline & Not germinated & 6 & 16.66 & 4 & 13.33 \\
\hline & Damaged & 16 & 53.33 & 21 & 70.00 \\
\hline \multirow[t]{3}{*}{ Acacia auriculiformis } & Germinated & 18 & 60.00 & 14 & 46.66 \\
\hline & Not germinated & 5 & 16.66 & 9 & 30.00 \\
\hline & Damaged & 7 & 23.33 & 7 & 23.33 \\
\hline \multirow[t]{3}{*}{ Dipterocarpus turbinatus } & Germinated & 10 & 33.33 & 12 & 40.00 \\
\hline & Not germinated & 11 & 36.66 & 13 & 43.33 \\
\hline & Damaged & 9 & 30.00 & 5 & 16.66 \\
\hline \multirow[t]{3}{*}{ Syzygium grande } & Germinated & 13 & 43.33 & 17 & 56.66 \\
\hline & Not germinated & 5 & 16.66 & 3 & 10.00 \\
\hline & Damaged & 12 & 40.00 & 10 & 33.33 \\
\hline \multirow[t]{3}{*}{ Swietenia mahagoni } & Germinated & 16 & 53.33 & 15 & 50.00 \\
\hline & Not germinated & 8 & 26.66 & 9 & 30.00 \\
\hline & Damaged & 6 & 20.00 & 6 & 20.00 \\
\hline
\end{tabular}

\section{Growth performance based on height and diameter:}

Swietenia mahagoni: Height growth of S. mahagoni seedlings in deforested soil was almost similar compared to natural forest soil for all the growth period. Collar diameter of the seedlings grown in deforested soil was significantly $(\mathrm{p} \leq 0.05)$ lower at three and six month age, and for other period slightly lower compared to the natural forest soil. Collar diameter of S. mahagoni at 15 month age in deforested soil was $1.24 \pm 0.13 \mathrm{~cm}(\mathrm{n}=5)$ and in natural forest soil $1.33 \pm 0.18 \mathrm{~cm}(\mathrm{n}=5)$ (Table 2$)$.

Dipterocarpus turbinatus: Height growth of $D$. turbinatus seedlings was almost similar in deforested soil compared to natural forest soil. Height of the seedlings at 15 month age in deforested soil was $46 \pm 7.04 \mathrm{~cm}(\mathrm{n}=5)$ and in natural forest soil $45 \pm 7.21 \mathrm{~cm}(\mathrm{n}=5)$ (Table 2). Reverse trend was found in collar diameter growth of the species. Collar diameter of D. turbinatus was slightly higher for all the growth period in deforested soil compared to natural forest soil. Collar diameter of the species at 15 month age in deforested soil was $0.88 \pm 0.08 \mathrm{~cm}(\mathrm{n}=5)$ and in natural forest soil $0.86 \pm 0.08 \mathrm{~cm}(\mathrm{n}=5)$ (Table 2).

Gmelina arborea: Height growth of $G$. arborea seedlings on deforested soil was almost similar to slightly lower compared to natural forest soil. Height of the species at 15 month age in deforested soil was $80.90 \pm 7.91 \mathrm{~cm}(\mathrm{n}=5)$ and in natural forest soil $89.90 \pm 9.50 \mathrm{~cm}(\mathrm{n}=5)$. Collar diameter of $G$. arborea was lower at all the ages of seedlings compared to natural forest soil (Table 2). It clearly showed that the height, collar diameter of 10 individuals for both sites with very close differences. The trend focused that significant variation may create in near future between two land uses.

Acacia auriculiformis: Height growth of A. auriculiformis seedlings grown on deforested soil was significantly $(\mathrm{p} \leq 0.05)$ lower at three month age, and for other period slightly lower compared to natural forest soil. At 15 month age, $A$. auriculiformis seedlings attained only $105.0 \pm 14.44 \mathrm{~cm}(\mathrm{n}=5)$ in deforested soil and $116.0 \pm 12.41 \mathrm{~cm}(\mathrm{n}=5)$ in natural forest soil. 


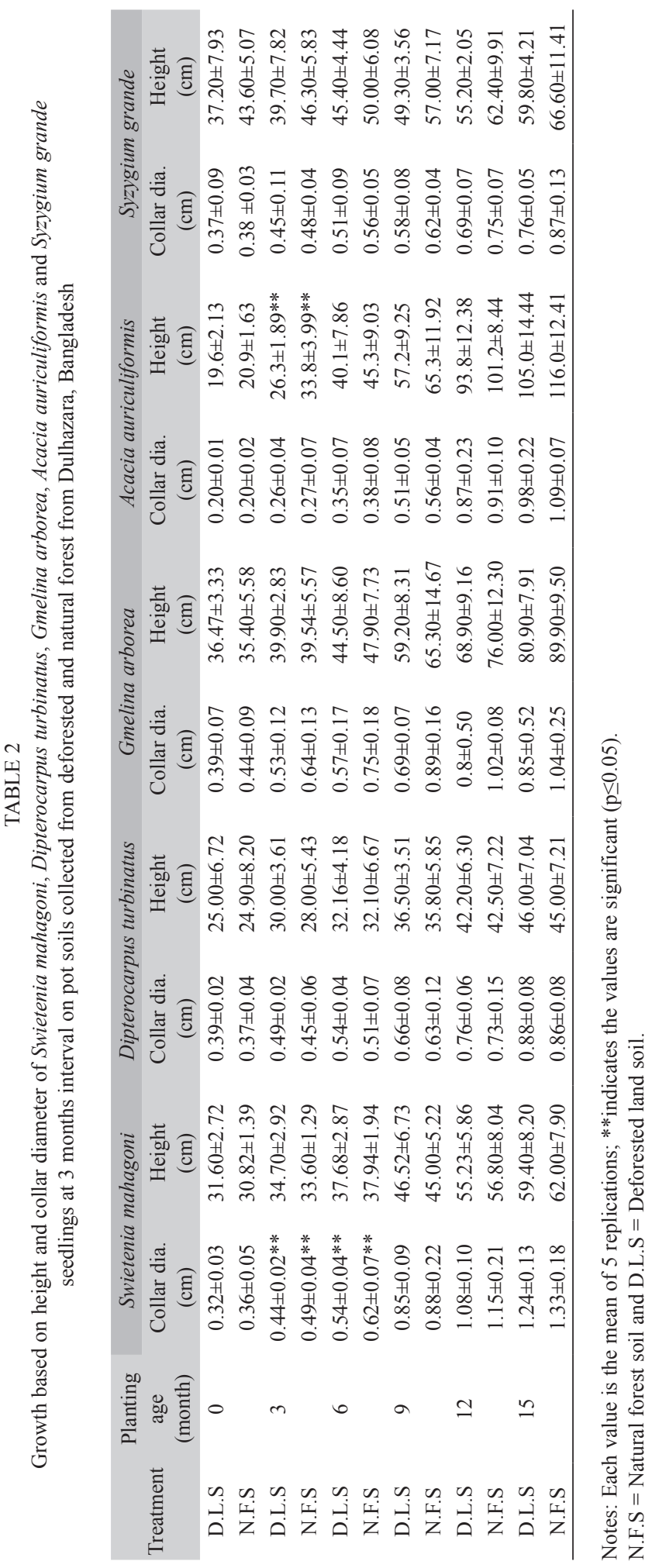


Collar diameter of A. auriculiformis was lower compared to natural forest soil. Collar diameter of the species at 15 month age in deforested soil was $0.98 \pm 0.22 \mathrm{~cm}(\mathrm{n}=5)$ and in natural forest soil $1.09 \pm 0.07 \mathrm{~cm}(\mathrm{n}=5)$ (Table 2).

Syzygium grande: Growth of $S$. grande seedlings grown on deforested soil was lower compared to natural forest soil for all the growth period. Height of the species at 15 month age in deforested soil was $59.80 \pm 4.21 \mathrm{~cm}(\mathrm{n}=5)$ and in natural forest soil $66.60 \pm 11.41 \mathrm{~cm}(\mathrm{n}=5)$. Collar diameter of $S$. grande was slightly lower for all the growth period in deforested soil compared to natural forest soil (Table 2).

Growth performance based on biomass production: Growth based on oven dry weight of $G$. arborea seedlings and root was significantly $(\mathrm{p} \leq 0.05)$ lower and other component parts slightly lower in deforested soil compared to natural forest soil (Fig. 2). Oven dry weight of $G$. arborea seedlings at 19 month age in deforested soil was $30.56 \mathrm{~g}(\mathrm{n}=5)$ and in natural forest soil 43.69g $(\mathrm{n}=5)$. At 19 month age, reverse trend was found for $S$. mahagoni and their component parts, i.e. S. mahagoni seedlings and leaf significantly $(\mathrm{p} \leq 0.05)$ higher and other component parts slightly higher in deforested soil compared to natural forest soil (Fig. 2). Oven dry weight of $S$. mahagoni seedlings at 19 month age in deforested soil was $41.13 \mathrm{~g}(\mathrm{n}=5)$ and in natural forest soil $28.95 \mathrm{~g}$ $(\mathrm{n}=5)$. Similar trend was also found for $D$. turbinatus and their component parts at 19 month age. At 19 month age, growth of $S$. grande seedlings based on oven dry weight was almost similar, root higher and branch growth lower in deforested soil compared to natural forest soil. Similarly, oven dry biomass production of $A$. auriculiformis seedlings and root were higher and branch growth lower in deforested soil compared to natural forest soil (Fig. 2). Oven dry weight of the seedlings at 19 month age in deforested soil was $55.60 \mathrm{~g}(\mathrm{n}=5)$ and in natural forest soil 48.82g $(n=5)$.

\section{DISCUSSION}

The results of seed germination and seedling growth of the present study clearly demonstrated that deforested soils still had the conditions for survival and growth of tree seedlings in Dulhazara. In the study, though fairly large amount of seeds were damaged, germination rate of the species in deforested soil was found satisfactory when compared to natural forest soil. Almost similar germination percentage in both types of land uses in the study indicated that condition of deforested areas still favor seed germination.

Instead of favorable condition for seed germination in deforested land at Dulhazara, germination rate of the studied species were quite low when compared to findings from Pareliussen et al. (2006) and Anderson (1866), because of excessive biotic interference i.e. wildlife (deer, sambur, wild boar among others in forest soil seedbeds and domestic animals (cows, dogs, goats, etc.) in deforested soil seedbeds. Besides, higher seed damage of $G$. arborea and $S$. grande were because, seeds of these species are the favorite food for many wild birds and animals. Islam et al. (1999) also reported harmful impact of biotic interference on germination and initial growth of tree seedlings.

However, the alteration of microclimate during germination could also limit the seed germination and result in a negative feedback by the plant as growth progresses. Though height growth $S$. mahagoni was almost similar in both types of land use, a significant variation was observed in collar diameter growth, which depicts negative influence of deforested soils. Anderson (1866) revealed that under favorable conditions within seven months $S$. mahagoni obtained similar height that observed after 15 month age in the study. The reason might be close affection of $S$. mahagoni seedlings towards flat sandy alluvium (Chowdhury et al. 2004), but sandy loam and clay to silt clay soil were used in the present experiment. 

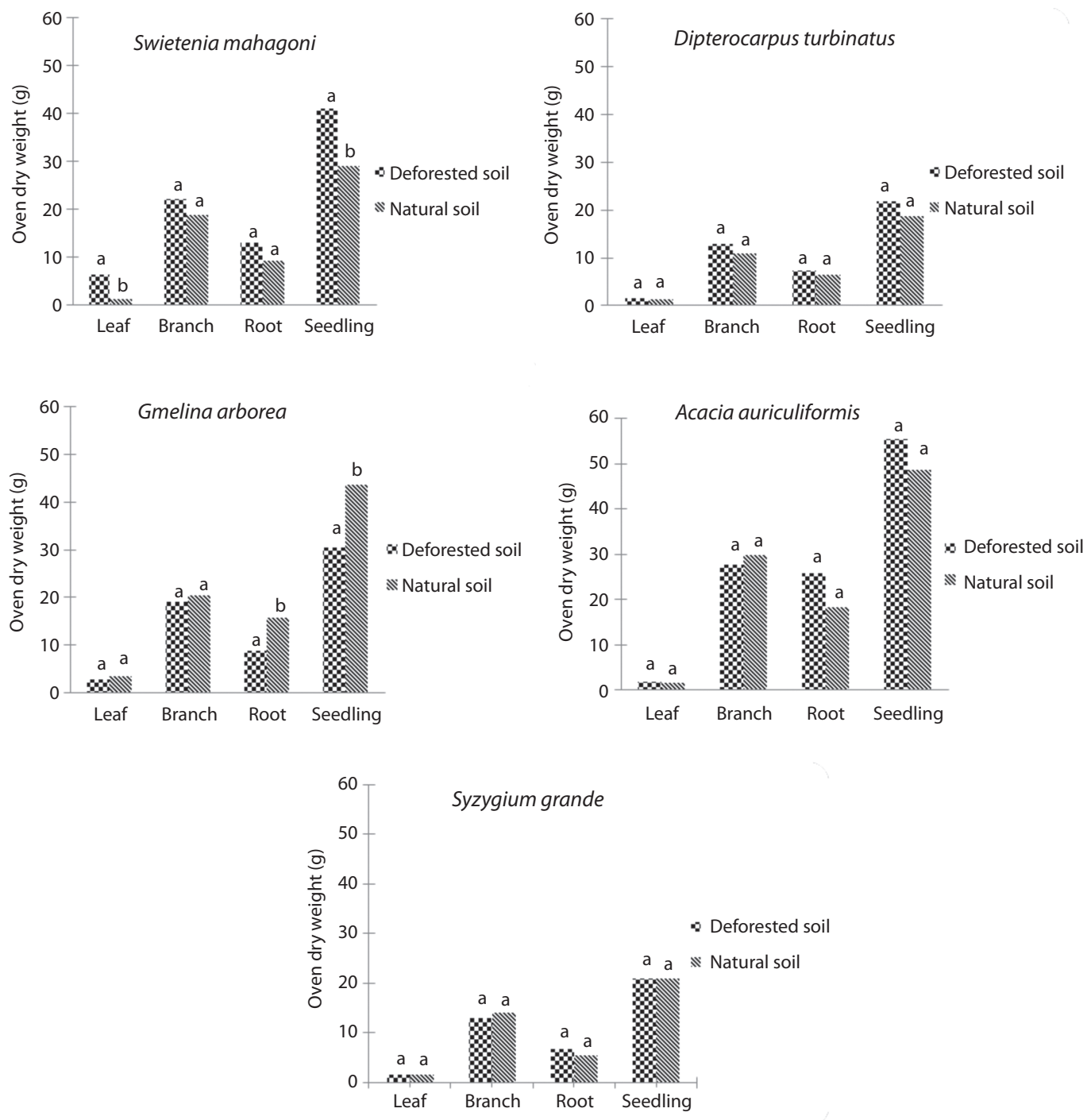

Fig. 2. Growth based on oven dry biomass of Swietenia mahagoni, Dipterocarpus turbinatus, Gmelina arborea, Acacia auriculiformis and Syzygium grande seedlings with their component parts at 19 month age on pot soils from deforested and natural forest of Dulhazara, Bangladesh. Notes: Different letters on the graph indicate significant difference $(\mathrm{p} \leq 0.05)$ between the means of natural and deforested soils and each bar is the mean of five replicates.

Although Shono et al. (2007) reported a poor survival and growth of reforested tree species in degraded lands, in this study $S$. mahagoni obtained higher height and the oven dry biomass compared to all other studied species, and indicate its adaptability in such deforested land to some extent.

Among the other studied species D. turbinatus is a natural and native tree species of this region, which also responded quite well to the deforested soils. D. turbinatus seedlings at one year age attained height of $0.92 \mathrm{~m}$ in natural forest soil and $0.86 \mathrm{~m}$ in deforested soil. Beniwal (2006) conducted an experiment on D. turbinatus seedlings growing in forest area and found heights of $0.27 \mathrm{~m}$ at one year age. In the study, height growth of $D$. turbinatus was comparatively higher due to growing in nursery 
with taking more care and maintenance compared to seedlings grown in field (Blanford 1915). Besides, growth has been found to vary with climatic condition of sites, microsite differences in soil drainage, nutrient status and genetic variation, which interact to influence diameter increments of individual trees and resulting wide inter-individual variability in growth rates (Whigham et al. 1998, Lamb 1966, Bird 1998). In the current study, $A$. auriculiformis seedlings attained only $1.90 \mathrm{~m}$ in deforested soil at 15 month age while in Srilanka A. auriculiformis was reported to grow up to $6.70 \mathrm{~m}$ in one and half year, and $5 \mathrm{~m}$ after two year in U.S.A. with 1x1m spacing (Mahmud et al. 2005). Though in the present study height growth of $\mathrm{A}$. auriculiformis was found lower than that in Sri Lanka and USA, but among the other studied species, it was found to be a highly adaptable species in terms of germination rate, height growth and dry biomass production. Several other authors have also reported that $A$. auriculiformis grow well in a wide range of soils under different conditions (Nas 1980, Akkasaeng et al. 1989, Duguma et al. 1994, Kamara \& Maghembe 1994). This fast-growing tree has extensive root systems with profuse bundles of $\mathrm{N}$-fixing nodules that have allowed them to survive and grow on degraded sites, compete with weeds successfully, and improve the soil characteristics over time (Nas 1980, Cole et al. 1996).

The growth trend of tree seedlings in the study also focused that nutrient deficiency may be created in near future in deforested land. Therefore, to protect the environment from ecological disaster as well as for sustainable production from plantation forest, such deforested land should be covered immediately through the plantation of $A$. auriculiformis, $G$. arborea, $S$. mahagoni, D. turbinatus, $S$. grande and $S$. mahagoni. Though, D. turbinatus was not showed satisfactory growth performance in deforested land, still it is preferred to be planted along with other species considering their value in biodiversity conservation. In addition, other common species of the region are needed to be tested for rehabilitating such degraded land in future. Further, sustainable development programs need to be spread among the people so that they can live in harmony with the forest without destroying it.

\section{ACKNOWLEDGMENTS}

The author thanks USDA for funding this study and all the IFESCU nursery staff for their considerate help.

\section{RESUMEN}

La destrucción de los bosques naturales se está incrementando debido a la urbanización y la industrialización, así como por la expansión agrícola en las últimas décadas, por lo tanto deben llevarse a cabo los respectivos estudios para su recuperación. Este estudio comparativo fue diseñado para ver los efectos de la tierra deforestada en la germinación y crecimiento de cinco especies diferentes de árboles. Las especies Gmelina arborea, Swietenia mahagoni, Dipterocarpus turbinatus, Acacia auriculiformis y Syzygium grande fueron germinadas por seis semanas en semilleros y criadas en macetas que se llenaron con dos tipos de tierra: de los bosques deforestados y los adyacentes de Dulhazara Safari Park. El crecimiento de plántulas se observó por 15 meses basándose en altura, diámetro del cuello y producción de biomasa. La tasa de germinación fue casi similar en ambos tipos de tierra. El crecimiento en altura de plántulas de D. turbinatus, G. arborea y $S$. mahagoni fue casi similar y para $A$. auriculiformis y $S$. grande fue menor en el suelo deforestado en comparación con el bosque, mientras que el diámetro del cuello de $\mathrm{A}$. auriculiformis, G. arborea, S. grande y S. mahagoni fue inferior y D. turbinatus similar en la tierra deforestada comparada con la del bosque. Después de arrancar de raíz a los 19 meses, S. mahagoni mostró mayor biomasa seca, así como $D$. turbinatus y A. auriculiformis, mientras que G. arborea mostró ser más baja y $S$. grande casi similar en ambos tipos de suelo. Las diferencias en la tasa de germinación y de crecimiento para diferentes especies de árboles indica que el suelo no está muy deteriorado por la deforestación en Dulhazara y sin fallar esas tierras deforestadas podrían ser restauradas a través de la plantación.

Palabras clave: deforestación, crecimiento, biomasa seca, desecadores, Dulhazara Safari Park, Bangladesh

\section{REFERENCES}

Ahmed, G.U. 1990. Survival Percentage and Growth Statistics of Some Plantation Species at Chittagong University Campus. Chittagong University Studies Part II. Science. 14: 45-50.

Akkasaeng, R., R.C. Gutteridge \& M. Wanapat. 1989. Evaluation of trees and shrubs for forage and fuelwood in Northeast Thailand. Int. Tree Crops J. 5: 209-220. 
Anderson, T. 1866. Indian forester, XXXIX (1913): 327.

Beniwal, B.S. 2006. Genetic improvement of forest trees in Arunachal Pradesh. Indian For. 116: 3-10.

Bird, N.M. 1998. Sustaining the Yield: Improved Timber Harvesting Practices in Belize 1992-1998. Natural Resources Institute, University of Greenwich, United Kingdom.

Blanford, H.R. 1915. Indian Forester, 12: 78.

Carpenter, F.L., J.D. Nichols \& E. Sandi. 2004. Early growth of native and exotic trees planted on degraded pasture. Forest Ecol. Manag. 196: 367-378.

Chowdhury, J.K., S.R. Biswas, S.M. Rahman \& S.N. Uddin. 2004. Biodiversity of Dulahazara Safari Park, Cox's Bazar. IUCN Bangladesh Country Office, Dhaka, Bangladesh.

Cole, T.G., R.S. Yost, R. Kablan \& T. Olsen. 1996. Growth potential of twelve Acacia species on acid soils in Hawaii. Forest Ecol. Manag. 80: 175-186.

Dinerstein, E., D.M. Olson, D.J. Graham, A.L. Webster, S.A. Primm, M.P. Bookbinder \& G. Ledec. 1995. A conservation assessment of the terrestrial ecoregions of Latin America and the Carribean. World Wildlife Fund/World Bank, Washington, DC, USA.

Douglas. 1981. Quoted in Village Forest Inventory, Statistical Report Forestry Master Plan, 1992.ADB (TA 1355-BAN), UNDP/FAO/BGD/025/1992. Ministry of Environment and Forests, Government of Bangladesh, Bangladesh.

Dugua. B., J. Tonye, J. Kanmegne, T. Manga \& T. Enoch. 1994. Growth of ten multipurpose tree species on acid soils in Sangmelina, Cameroon. Agroforest. Syst. 27: 107-119.

Evans. J. 1982. Plantation forestry in the tropics. Clarendon, Oxford, United Kingdom.

FAO. 1995. Forest Resources Assessment 1990: Global Synthesis. FAO Forestry Paper 124. Rome, Italy.

FAO. 2001. Technical Notes on Forestry Aspects. WFP Assisted Projects. November 1993, FAO, Dhaka, Bangladesh.

FMP. 1992. Main Plan -1993/2012 and supporting volumes, Forestry Master Plan, Bangladesh, Asian Development Bank (TA No. 1355-BAN). UNDP /FAO / $\mathrm{BGD} / 88 / 025$.

FRA. 2000. Forest resources of Bangladesh country report. FAO, Rome, Italy.

Houghton, R.A. 1990. The future role of tropical forests in affecting the $\mathrm{CO}_{2}$ concentration in the atmosphere. Ambio 19: 204-209.

Islam, K.R., M. Kamaluddin, M.K. Bhuyan \& A. Badruddin. 1999. Comparative performance of exotic and indigenous forest species for tropical semi- evergreen degraded forest land reforestation in Chittagong, Bangladesh. Land Degrad. Dev. 10: 241-249.
Islam, K.R. \& R.R. Weil. 2000. Land use effects on soil quality in a tropical forest ecosystem of Bangladesh. Agr. Ecosyst. Environ. 79: 9-16.

Kamara, C.S. \& J.A. Maghembe. 1994. Performance of multipurpose tree and shrub species 28 months after planting at Chalimbana, Zambia. Forest Ecol. Manag. 64: 145-151.

Lamb, F.B. 1966. Mahogany of Tropical America: its Ecology and Management. The University of Michigan Press, Ann Arbor, USA.

Lusiana. B., P. Purnomosidhi, S. Rahayu \& J. Roshetko. 2004. Survival and Initial Growth of Various Timber Trees Species in Degraded Soils of North Lampung, Indonesia.

Mabud, A. 2001. Integrated Forest Management Plan For Chittagong Forest Division (2002-2009). Final Draft Book no. 1. Forest Department, Bangladesh.

Mahmud, S., A.T.M.R. Hoque \& M. Mohiuddin. 2005. Germination behavior and initial growth performance of eight multipurpose tree species. Int. J. Agric. Biol. 4: 539-542.

Munsell Soil Color Charts. 1954. Munsell Color Company, Inc., Baltimore, USA.

Nas. 1980. Firewood Crops - Shrubs and Tree Species for Energy Production, National Academy of Sciences, Washington DC, USA.

Pareliussen, I., E.G.A. Olsson \& W.S. Armbruster. 2006. Factors limiting the survival of native tree seedlings used in conservation efforts at the edges of forest fragments in upland Madagascar. Restor. Ecol. 14: 196-203.

Pritchett, W.L. \& R.F. Fisher. 1987. Properties and Management of Forest Soils. John Wiley and Sons, New York, USA.

Rasul, G. \& M. Kakri. 2007. Participatory Forest Management in South Asia. A comparative analysis of policies, institutions and approaches. Published by ICIMOD, Kathmandu, Nepal.

Roshetko, J.M. \& P. Purnomosidhi. 1999. Establishment and early growth of five timber species under smallholder conditions in Lampung, Indonesia. Forest Farm and Community Tree Research Reports. 4: 4-10.

Shono, K., S.J. Davies \& Y.K. Chua. 2007. Performance of 45 native tree species on degraded lands in Singapore. J. Trop. For. Sci. 19: 25-34.

WCMC. 1998. Directory of South Asian Protected Areas. IUCN. 95-113.

Whigham, D.F., J.F. Lynch \& M.B. Dickinson. 1998. Dynamics and ecology of natural and managed forests in Quintana Roo, Mexico, p. 267-281. In R.B. Primack (eds.). Timber, tourists, and temples: conservation and development in the Maya Forests of Belize, Guatemala and Mexico. Island, Washington DC, USA. 
